\title{
FP fights for earthquake-proof schools in BC
}

Every day, Tracy Monk tackles the usual health issues of a family practice. When she takes off her stethoscope, though, her life-saving mission is even more daunting: Monk is determined to protect thousands of children from crumbling schools in BC's next earthquake.

Older schools built of masonry are disproportionately less stable than other buildings. And since $\mathrm{BC}$ is in an earthquake zone, even a moderate tremor is a risk for up to 500 schools housing 30000 children. A major quake would kill at least 290 people and injure 1000 in schools.

Monk's 9-year-old daughter $\sim$ began attending a masonry school last year, shortly after earthquakes struck Italy and Turkey. There, school buildings had collapsed while other buildings stood. Monk wondered why. She looked up a 1989 Vancouver school board report that predicted local schools - including her daughter's - would collapse at 100 times the rate of a wood frame house. "I wanted to throw up," she recalls.

Monk's 150-member group, Families for School Seismic Safety (FSSS), is backed by provincial public health authorities and engineers. Seismic upgrading - basically reinforcing walls - is dirt cheap when cost is calculated per year of life saved, she says. For about $\$ 500$ million, seismic upgrades "would protect generations of inhabitants."

The group has had some success. Victoria and Ottawa agreed to fund a seismic risk assessment, and the recent $\mathrm{BC}$ budget committed some money, but not for another 2 years. Monk wants federal-provincial cooperation and funding to prevent a disaster.

Elsewhere, Long Beach, California, has already upgraded its schools, while Washington State

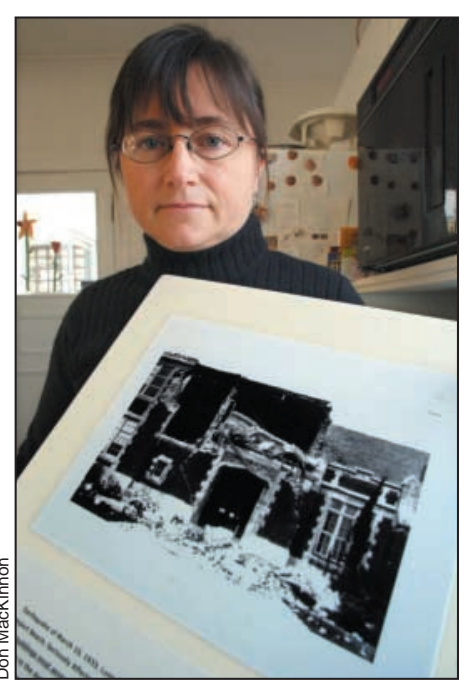

Historic precedent: Dr. Tracy Monk is lobbying for seismic upgrading of BC schools.

will be finished upgrading in 4 years. At its current pace, BC schools won't become seismically safe for another 60 years. - Deborab fones, Whistler, BC

\section{LeGAL IsSUES}

\section{Breast cancer patients sue over radiotherapy wait times}

Quebec Superior Court Justice John Bishop has authorized a class action suit on behalf of 10000 Quebec breast cancer patients who contend they had to wait too long for radiotherapy.

"This is the first time someone has taken action against waiting lists," says Montréal lawyer Michel Savonitto, who filed the suit in 2000 at the request of a Montréal woman. Bishop's precedent-setting ruling could open the door to similar lawsuits across Canada.

Anahit Cilinger had a partial mastectomy with lymph node $\approx$ removal in October 1999 and was put on a waiting list for radiotherapy. Twelve weeks later, she was still waiting.

There was no place in Quebec where she could receive radiotherapy, and she couldn't get confirmation of plans to send her to the US. Angry and anxious, she returned to her native Turkey, where she paid US\$12 000 for radiotherapy at an Istanbul hospital.

"Nobody could tell her what the final delay would be," says Savonitto. "For her, it was unacceptable."

Cilinger spearheaded the class action suit. "I don't want other women to suffer the way I did while I was waiting for my treatment," she said.

If the suit is successful, Savonitto estimates it could cost hospitals $\$ 25$ million to $\$ 50$ million.

Savonitto filed more than a dozen medical articles to back his case. The evidence convinced Bishop that a medically acceptable delay between breast cancer surgery and radiotherapy ranges from 8 to 12 weeks. In his $41-$ page decision, delivered Mar. 9, he acknowledged a higher risk of breast cancer recurrence exists after longer delays.

Hospital administrators at the dozen Quebec hospitals named in the lawsuit may have to defend their decisions in court.

The court must decide what constitutes an acceptable standard of care for women who need radiotherapy after breast cancer surgery. The real question, says Margaret Somerville, founding director of the McGill Centre for Medicine, Ethics and Law, is whether failing at that standard constitutes negligence.

"These time periods seem very important," she admits, "but this is a zero-sum game. There's only so much money [in the health care system]. What do we do?" - Heather Pengelley, Montréal, Que.
"The ad hoc experts' group finds it unconscionable that schools built world-wide routinely collapse in earthquakes due to avoidable errors in design and construction, causing predictable, unwarranted, unacceptable and tragic loss of life." OECD World Conference resolution, 2004 